Acta vet. scand. $1973,14,332-334$.

Brief Communication

\title{
MYCOPLASMOSIS: EXPERIMENTAL SEMINAL VESICULITIS. DEMONSTRATION OF LOCALLY OCCURRING ANTIBODY
}

1. Infections with $\mathrm{M}$. bovigenitalium are of ten characterized by the presence of leucocytes with eosinophilic granules. Parsonson (1970) holds that the persistance of mycoplasmas in the genital tract of bulls provides a constant source of antigen which can combine with locally produced antibodies to form antigenantibody complexes which attract eosinophils.

2. In experimental mycoplasmal infections of the genital tract of bulls a significant increase in serum antibody could be demonstrated, but as the titers were low and the maximum titers were reached early, it was concluded that it would not of ten be possible to make a clinical diagnosis on the basis of examination of serum. It was suggested that serological examination of seminal plasma could be of diagnostic value (Ern $\varnothing$ 1972).

The present communication reports the results of an experiment designed to elucidate aspects of the above questions, i.e. appearance of mycoplasmal antibodies at the site of inoculation and the possible diagnostic value of serological examination of seminal plasma. The latter problem was elucidated also by titration of 40 random samples of semen from normal AI bulls.

Inoculation. Twin bulls, nos. 185 and $186,2 \frac{1}{2}$ years old, were inoculated in the left vesicular glands with $5 \times 2 \mathrm{ml}$ of a 48 -hourold broth culture of $M$. bovigenitalium, strain " $K$ ", containing $10^{8}$ colony forming units (c.f.u.) per $\mathrm{ml}$. The bulls were slaughtered 40 days after inoculation (p.i.).

Immunological tests. Serum and seminal plasma were examined by 2 serological tests, viz. indirect hemagglutination (IHA) and tetrazolium reduction inhibition (TRI). Secretion from the vesicular glands were tested by IHA and also by indirect immunofluorescence to demonstrate possible appearance of mycoplasmal antibodies within the known immunoglobulin classes (Ern $\phi \&$ Aalund 1972). 


\section{Results}

The results obtained in one of the experimental bulls (no. 186) are summarized in Table 1 , and the results of serological examination and cultivation of vesicular secretions from both bulls are seen in Table 2.

Table 1. Experimental vesiculitis induced by $M$. bovigenitalium (bull no. 186).

\begin{tabular}{|c|c|c|c|c|c|c|c|}
\hline \multirow[b]{3}{*}{$\begin{array}{l}\text { Days } \\
\text { p.i. }\end{array}$} & \multirow[b]{3}{*}{$\begin{array}{l}\text { Clinical } \\
\text { changes }\end{array}$} & \multirow[b]{3}{*}{$\begin{array}{l}\text { Pus cells } \\
\text { in semen }\end{array}$} & \multirow{3}{*}{$\begin{array}{c}\text { Colony } \\
\text { forming } \\
\text { units } / \mathrm{ml} \\
\text { of semen }\end{array}$} & \multicolumn{4}{|c|}{$\begin{array}{l}\text { Antibodies in seminal plasma } \\
\text { and serum }\end{array}$} \\
\hline & & & & \multicolumn{2}{|c|}{ titer (IHA) } & \multicolumn{2}{|c|}{ titer (TRI) } \\
\hline & & & & sem.pl. & serum & sem.pl. & serum \\
\hline 0 & 0 & 0 & 0 & 0 & 0 & 1024 & 0 \\
\hline 4 & 0 & 0 & $10^{4}$ & 256 & 8 & 256 & 0 \\
\hline 7 & 0 & 0 & $8 \times 10^{7}$ & 32 & 64 & 128 & 0 \\
\hline 18 & 0 & 0 & $4 \times 10^{5}$ & 64 & 64 & 256 & 0 \\
\hline 21 & $(+)$ & 0 & $10^{8}$ & 128 & 64 & 256 & 0 \\
\hline 32 & + & + & $2 \times 10^{8}$ & 512 & 128 & 256 & 0 \\
\hline 35 & + & ++ & $4 \times 10^{8}$ & 256 & 128 & 8 & 0 \\
\hline 40 & + & $+t$ & NT & NT & 128 & NT & 0 \\
\hline
\end{tabular}

NT: Not Tested.

T a b l e 2. Serological examination of vesicular secretion (post mortem). Indirect hemagglutination.

\begin{tabular}{lccccc}
\hline \multirow{2}{*}{$\begin{array}{l}\text { Bull } \\
\text { no. }\end{array}$} & \multicolumn{2}{c}{ Left vesicular gland } & & \multicolumn{2}{c}{ Right vesicular gland } \\
\cline { 2 - 3 } $\begin{array}{c}\text { c.f.u. per ml } \\
\text { of secretion }\end{array}$ & titer (IHA) & & $\begin{array}{l}\text { c.f.u. per ml } \\
\text { of secretion }\end{array}$ & titer (IHA) \\
\hline 185 & $10^{7}$ & 0 & & $8 \times 10^{2}$ & 0 \\
186 & $3 \times 10^{3}$ & 5,120 & & 0 & 0 \\
\hline
\end{tabular}

Antibodies did appear very early in seminal plasma as measured by IHA. The TRI test was not applicable, as metabolic inhibiting factors were present before inoculation. Antibodies were demonstrable by IHA in 18 of the 40 random semen samples. The average titer of positive samples was 1:400. In bull 186 antibodies were demonstrable in secretion from the inoculated gland. In bull 185 antibodies were not found in either of the 
glands, but it is important to note that in the inoculated gland of this animal a high count of mycoplasmas was found, which may have neutralized possible antibody present. Antibodies of all known bovine immunoglobulin classes (IgM, IgA, IgG-1, IgG-2) were present in the secretion of the inoculated gland of bull 186 .

\section{Conclusions}

1. Antibody may be present locally at the site of inoculation, with which one of the prerequisites for the correctness of the theory of Parsonson is fulfilled. 2. Serological examination of seminal plasma is not of diagnostic importance, as antibody often occurs in seminal plasma of healthy bulls.

\section{Henning Ernø}

The FAO/WHO International Reference Centre

for Animal Mycoplasmas,

Institute of Medical Microbiology,

University of Aarhus, Denmark.

Ertk Blom

The State Veterinary Serum Laboratory, Copenhagen, Denmark.

\section{REFERENCES}

Ern $\varnothing, H .:$ Mycoplasmosis: Serology of infections in the genital tract of bulls. Infect. Immunity 1972, 5, 20-23.

Ernø, H. \& O. Aalund: Mycoplasmosis: Experimental mastitis. Immunoglobulin classes of mycoplasmal antibodies in milk and serum. Acta vet. scand. 1972, 13, 597-599.

Parsonson, I. M.: Mycoplasma bovigenitalium: Experimental induction of genital disease in bulls. Thesis, Cornell University 1970.

(Received December 1, 1972).

Reprints may be requested from: E. Blom, The State Veterinary Serum Laboratory, DK-1870 Copenhagen V, Denmark. 